\title{
STUDI KOMPARATIF AKTIVITAS DAN HASIL BELAJAR MENGGUNAKAN MODEL PEMBELAJARAN KOOPERATIF TIPE MAKE A MATCH PADA MATA PELAJARAN IPS DI SMP NEGERI 1 SUKASADA
}

\author{
Ni Made Masini ${ }^{1}$, lyus Akhmad Haris ${ }^{2}$, Luh Indrayani ${ }^{3}$ \\ Program Studi Pendidikan Ekonomi \\ Universitas Pendidikan Ganesha \\ Singaraja, Indonesia \\ e-mail: kadek.mtk14@gmail.com¹, iyusharis55@gmail.com² \\ luh indrayani@undiksha.ac.id ${ }^{3}$
}

\begin{abstract}
Abstrak
Penelitian ini bertujuan untuk mengetahui perbedaan aktivitas belajar, perbedaan hasil belajar, dan perbedaan aktivitas dan hasil belajar pada mata pelajaran IPS kelas VIII SMP Negeri 1 Sukasada. Jenis penelitian ini adalah eksperimen semu. Subjek dalam penelitian ini adalah siswa kelas VIII F sebagai kelas eksperimen dan kelas VIII E sebagai kelas kontrol. Objek dalam penelitian ini adalah aktivitas belajar, hasil belajar dan model kooperatif tipe make a match. Selanjutnya analisis yang digunakan adalah uji Manova. Hasil penelitian menunjukkan bahwa terdapat perbedaan aktivitas belajar antara siswa yang dibelajarkan dengan model kooperatif tipe make a match dengan model konvensional ditunjukkan dari nilai signifikansi $0,040<0,05$, terdapat perbedaan hasil belajar antara siswa yang dibelajarkan dengan model pembelajaran kooperatif tipe make a match dengan model konvensional ditunjukkan dari nilai signifikansi $0,000<0,05$, dan terdapat perbedaan aktivitas dan hasil belajar antara siswa yang dibelajarkan dengan model pembelajaran kooperatif tipe make a match dengan model konvensional ditunjukkan dari nilai signifikansi $0,000<0,05$.
\end{abstract}

Kata kunci: pembelajaran kooperatif, make a match, aktivitas, hasil belajar.

\begin{abstract}
This study aims to know the differences in learning activities, learning outcomes, and differences in the activity and learning outcomes of Social Science subjects of class VIII SMP Negeri 1 Sukasada. This study is quasi experiment. The subject in this study is class VIII F as an experiment class, class VIII E as a control class. The objects in this study are activities outcomes, the learning outcomes and cooperative learning model type make a match. Next, the analysis which is used is the Manova test. The results showed that there is a difference between learning activities of students who taught with cooperative learning model type make a match with conventional model shown from the value of significance of $0.040<$ 0.05 , there is a difference between learning outcomes between students who are taught with cooperative learning model type make a match with conventional model shown of the value significance of $0.000<0.05$, and there is a difference between learning outcomes and activities of students who are taught by cooperative learning model type make a match with conventional model shown from the value significance $0.000<0.05$.
\end{abstract}

Keywords: cooperative learning, make a match, activity, learning outcomes. 


\section{PENDAHULUAN}

Pendidikan merupakan wahana yang penting dalam pembinaan sumber daya manusia (Sagala, 2010). Oleh karena itu, pendidikan perlu mendapatkan perhatian yang lebih dari pemerintah, masyarakat, dan khususnya oleh pengelola pendidikan, agar tujuan pendidikan yang dicita-citakan dapat tercapai. Sejalan dengan pendapat Hamalik (2008) menyatakan bahwa pendidikan adalah proses mempengaruhi peserta didik dalam menyesuaikan diri dengan lingkungan dan dapat menimbulkan perubahan dalam dirinya sehingga memungkin berfungsi dengan baik dalam kehidupan masyarakat.

Sehubungan dengan hal tersebut, dalam Undang-undang Sistem Pendidikan Nasional Nomor 20 Tahun 2003 bab 2 pasal 3 disebutkan bahwa pendidikan nasional berfungsi untuk mengembangkan kemampuan dan membentuk watak serta peradaban bangsa yang bermartabat dalam rangka mencerdaskan kehidupan bangsa, tujuannya untuk mengembangkan potensi peserta didik agar menjadi manusia yang beriman dan bartakwa kepada Tuhan Yang Maha Esa, berakhlak mulia, sehat berilmu, cakap, kreatif, mandiri, dan menjadi warga negara yang demokratis serta bertanggung jawab. Atas dasar tersebut, pendidik haruslah memiliki profesionalisme yang kuat untuk bisa mengkondisikan kegiatan belajar mengajar yang kondusif. Dalam rangka mewujudkan hal tersebut, peran lembaga formal dalam hal ini sekolah sangat penting dalam meningkatkan mutu pendidikan.

Meningkatkan mutu pendidikan, tentu saja tidak terlepas dari proses belajar mengajar sebagai kegiatan utama di sekolah. Salah satu faktor yang sangat berpengaruh dalam kegiatan belajar mengajar yaitu dalam pemilihan model pembelajaran. Model pembelajaran terdiri dari berbagai macam, menurut Komalasari (2013) ada lima model pembelajaran yakni pembelajaran berbasis masalah, pembelajaran kooperatif, pembelajaran berbasis proyek, pembelajaran pelayanan, dan pembelajaran berbasis kerja. Pemilihan model pembelajaran tertentu akan sangat berpengaruh pada proses pembelajaran pada mata pelajaran yang diajarkan oleh pendidik. Mata pelajaran IImu Pengetahuan Sosial (IPS) sebagai salah satu mata pelajaran wajib yang perlu dipelajari oleh siswa di sekolah. Sampai sekarang masih banyak siswa yang menganggap bahwa pelajaran IPS sering menjadi momok bagi siswa Sekolah Menengah Pertama (SMP). Rata-rata siswa beranggapan bahwa IPS sebagai mata pelajaran yang berbentuk hafalan. Pola pikir tersebut membuat siswa menjadi malas untuk mempelajari IPS. Selain itu, ketidaktahuan siswa mengenai kegunaan IPS dalam praktek sehari-hari menjadi penyebab mereka cepat bosan dan tidak tertarik pada pelajaran IPS. Pendidik/guru IPS mengajar secara pasif, monoton, kurang inovatif, dan tidak menggunakan alat peraga juga menjadi penyebab siswa malas dalam mempelajari IPS.

Adapun faktor-faktor yang mempengaruhi hasil belajar menurut Slameto (2015) yaitu: faktor internal dan faktor eksternal. Faktor internal terdiri dari: faktor jasmaniah dan faktor psikologis. Faktor jasmaniah yang terdiri dari, kondisi fisik dan kondisi panca indera, faktor psikologis yang terdiri atas bakat, minat, kecerdasan, motivasi dan kemampuan kognitif. Faktor eksternal diantaranya: faktor keluarga, meliputi cara orang tua mendidik, relasi orang tua dengan anggota keluarga, suasana rumah, keadaan ekonomi keluarga, dan sebagainya, faktor sekolah yaitu metode mengajar, kurikulum, disiplin, alat pengajaran, keadaan gedung dan disiplin sekolah, dan faktor masyarakat kegiatan siswa dengan masyarakat, mass media dan teman bergaul.

Salah satu faktor yang
mempengaruhi hasil belajar adalah
aktivitas siswa dalam kegiatan belajar
mengajar yang terjadi di dalam kelas.
Pendidik sebagai fasilitator dalam proses
pembelajaran perlu menerapkan model
yang dapat meningkatkan aktivitas belajar
siswa dalam mata pelajaran IPS. Upaya
ini penting karena dengan melalui cara
pembelajaran yang baik siswa dapat
meningkatkan pemahaman terhadap


konsep-konsep IPS. Menurut Sardiman (2011) menyatakan bahwa kegiatan atau kesibukan yang dilakukan seseorang dalam belajar akan mempengaruhi hasil belajarnya. Siswa yang belajar dengan menulis, mengerjakan soal-soal, dan membuat rangkuman hasilnya akan lebih baik dari pada hanya membaca saja.

Realita yang ada di sekolah, pendidik masih mendominasi proses belajar mengajar dan siswa pasif dalam mengikuti proses pembelajaran. Aktivitas belajar siswa terbatas pada mendengarkan, mencatat, dan menjawab pertanyaan apabila guru memberikan pertanyaan. Sardiman (2011) menyatakan bahwa siswa menjadi pasif dalam proses pembelajaran semacam ini jelas tidak mendorong siswa untuk berfikir dan beraktivitas. Proses pembelajaran pada hakikatnya untuk mengembangkan aktivitas dan kreativitas siswa, melalui berbagai interaksi dan pengalaman belajar.

Dilihat dari kondisi siswa dalam proses belajar mengajar, peneliti mendapat gambaran bahwa selama pembelajaran berlangsung siswa kurang bersemangat untuk mengikutinya, banyak siswa yang mengantuk dan kurang termotivasi untuk terlibat dalam proses belajar. Siswa juga kurang aktif dalam melakukan diskusi karena kerjasama antara siswa yang masih minim untuk bertukar pikiran dan menyelesaikan suatu masalah. Hal ini ditunjukkan dengan pembahasan hal-hal yang tidak perlu dalam proses diskusi yang dilakukan oleh siswa atau bahkan dalam kelompok tertentu akan dijumpai siswa yang hanya terdiam ketika proses diskusi dilakukan. Penggunaan model pembelajaran yang monoton dalam proses pembelajaran juga akan menimbulkan kejenuhan. Misalnya, pendidik dalam menerangkan materi kepada siswa selalu menggunakan model ceramah atau konvensional yang membuat siswa merasa jenuh untuk mengikutinya. Oleh karena itu, setiap pembelajaran berlangsung hendaknya melibatkan seluruh siswa sehingga siswa dapat berpartisipasi secara aktif dengan materi yang sedang dibicarakan sehingga mampu meningkatkan pemahaman siswa.
Salah satu model pembelajaran yang dapat digunakan pada mata pelajaran IPS ialah model pembelajaran kooperatif atau cooperative learning. Pembelajaran kooperatif merujuk pada berbagai macam metode pengajaran dimana para siswa bekerja dalam kelompok-kelompok kecil untuk saling membantu sama lainnya dalam mempelajari materi pelajaran. Menurut Rusman (2012) Pembelajaran kooperatif ini memberikan banyak tipe yang dapat menciptakan semangat atau gairah siswa dalam belajar yang kemudian akan memunculkan keaktifan siswa dengan sendirinya.

Tipe pembelajaran kooperatif dibagi menjadi enam antara lain: Student Teams Achievement Divisison (STAD), Jigsaw, Investigasi Kelompok (Group Investigation), Make a Match (Membuat Pasangan), TGT (Teams Games Tournament) dan Struktural (Rusman, 2012). Tipe Make a Match merupakan model pembelajaran yang mengajak siswa mencari jawaban pertanyaan atau pasangan dari suatu konsep permainan kartu pasangan (Komalasari, 2013). Peneliti tertarik menerapkan model pembelajaran tipe make a match dalam pelajaran IPS sebab ada unsur permainan, meningkatkan pemahaman siswa terhadap materi yang dipelajari, efektif sebagai sarana melatih keberanian siswa untuk tampil presentasi, dan dapat meningkatkan aktivitas belajar siswa, baik secara kognitif maupun fisik.

Berdasarkan latar belakang masalah di atas, maka peneliti tertarik melakukan penelitian tentang Studi Komparatif Aktivitas dan Hasil Belajar Menggunakan Model Pembelajaran Kooperatif Tipe Make A Match pada Mata Pelajaran IPS di SMP Negeri 1 Sukasada

\section{METODE}

Jenis penelitian yang digunakan dalam penelitian ini adalah penelitian eksperimen semu. Penelitian eksperimen semu bertujuan untuk memperoleh informasi untuk mengungkapkan hubungan sebab akibat dengan melibatkan kelompok eksperimen dan kelompok kontrol untuk mengontrol semua 
variabel relevan (Sugiyono, 2008). Rancangan penelitian yang digunakan adalah rancangan eksperimen semu dalam bentuk Non-Equivalent Post-Test Only Control Group Design. Penelitian ini dilaksanakan secara kolaboratif dengan melibatkan guru mata pelajaran IPS pada kelas VIII SMP Negeri 1 Sukasada, dalam pelaksanaannya peneliti bertugas sebagai pengajar, sedangkan guru mata pelajaran IPS bertugas mengamati dan memberikan nilai pada lembar observasi aktivitas belajar dalam proses pembelajaran.

Prosedur penelitian dilakukan untuk menentukan tindakan-tindakan yang mengarahkan peneliti menjalankan penelitian. Langkah-langkah yang akan ditempuh dalam penelitian ini adalah orientasi dan observasi awal terhadap rancangan dan pelaksanaan pembelajaran untuk mengetahui keadaan kelas sebelum diberikan perlakuan, menentukan kelas yang digunakan untuk melakukan penelitian dengan konsultasikan kepada guru mata pelajaran IPS sehingga diperoleh kelas VIII E sebagai kelas kontrol dan VIII $F$ sebagai kelas eksperimen di SMP $N 1$ Sukasada, menentukan materi yang akan digunakan untuk penelitian, menyusun perangkat pembelajaran seperti: RPP dan LKS 1 Kompetensi Dasar untuk kelas eksperimen dan kelas kontrol yang dilaksanakan sebanyak 3 kali petemuan, 2 kali pertemuan memberikan treatment selanjutnya 1 kali memberikan post test yang dikonsultasikan dengan guru IPS dan dosen pembimbing, merevisi perangkat pembelajaran seperti RPP dan LKS untuk kelas eksperimen dan kontrol yang telah dikonsultasikan ke dosen pembimbing dan guru IPS terpadu, menyusun instrumen penelitian yang selanjutnya dikonsultasikan dengan dosen pembimbing dan guru IPS, memberikan perlakuan dengan menerapkan model pembelajaran kooperatif tipe make a match di kelas eksperimen dan model konvensional di kelas kontrol, merevisi instrumen penelitian yang telah dikonsultasikan dengan guru IPS dan dosen pembimbing, memberikan post-test yang sama kepada kelas kontrol dan kelas eksperimen, dan menganalisis data hasil penelitian untuk menguji hipotesis yang diajukan peneliti. Tempat pelaksanaan penelitian ini adalah di SMP Negeri 1 Sukasada yang berlokasi di desa Sukasada, Kecamatan Sukasada, Kabupaten Buleleng.

Subjek penelitian ini adalah subjek yang dituju untuk diteliti oleh peneliti. Subjek penelitian ini adalah siswa kelas VIII SMP Negeri 1 Sukasada yang terdiri dari delapan kelas. Siswa kelas VIII F yang berjumlah 28 orang sebagai kelas eksperimen dan siswa kelas VIII E yang berjumlah 27 orang sebagai kelas kontrol. Objek dalam penelitian ini adalah aktivitas, hasil belajar dan model kooperatif tipe make a match.

Data yang diperoleh dari hasil penelitian ini adalah data kuantitatif. Data kuantitatif adalah data yang diperoleh dari perhitungan angka-angka yang datanya didapat dari observasi aktivitas belajar dan hasil belajar yang diberikan kepada siswa mengenai penggunaan model pembelajaran kooperatif tipe make a match pada mata pelajaran IPS. Sumber data yang digunakan adalah data primer. Data primer adalah data yang diperoleh secara langsung dari sumber pertama yaitu dari siswa kelas VIII $E$ dan VIII $F$ SMP Negeri 1 Sukasada. Data yang dikumpulkan dalam penelitian ini adalah data mengenai aktivitas belajar dan hasil belajar siswa terhadap penerapan model pembelajaran kooperatif tipe make a match. Adapun metode pengumpulan data yang digunakan dalam penelitian ini sebagai berikut. Observasi, yang digunakan untuk memperoleh mengenai aktivitas belajar dalam kegiatan pembelajaran. Tes, yang digunakan untuk menilai hasil belajar yang diberikan pada siswa setelah diberikan pembelajaran 2 kali pertemuan dan akhir diberikan 1 posttest.

Data aktivitas belajar siswa dikumpulkan menggunakan lembar observasi aktivitas belajar siswa. caranya dengan mengamati secara langsung kegiatan yang dilakukan siswa saat proses pembelajaran berlangsung. Penilaiannya dilakukan dengan melihat deskripsi dari lembar observasi aktivitas belajar siswa yang tertuang dalam instrumen penelitian. 
Lembar observasi penilaian aktivitas belajar siswa terdiri dari 5 indikator aktivitas yang masing masing memiliki rentangan sekor 1 sampai 5 , sehingga skor aktivitas belajar maksimal yang bisa didapatkan oleh siswa adalah sebesar 25 .

Data hasil belajar siswa diperoleh dengan instrumen berupa tes hasil belajar. Bentuk tes yang diberikan dalam penelitian ini adalah tes pilihan ganda. Kriteria penilaian tes hasil belajar siswa adalah setiap item jawaban benar diberikan skor 1 dan jawaban salah diberikan skor 0 . Sebelum data digunakan sebelumnya data diujicobakan. Validitas adalah ukuran yang menunjukkan kevalidan dan keaslian suatu butir instrumen (Arikunto, 2013). Tes dapat dikatakan valid apabila tes tersebut mempunyai daya dukung yang besar terhadap skor total. Untuk mengukur tingkat validitas soal, digunakan rumus korelasi point biserial. Tingkat kesukaran soal adalah peluang untuk menjawab benar suatu soal pada tingkat kemampuan tertentu yang biasanya dinyatakan dalam bentuk indeks. Daya beda soal adalah kemampuan suatu butir soal untuk membedakan antara siswa yang telah menguasai materi yang ditanyakan dan siswa yang belum menguasai materi, dan Reliabilitas suatu perangkat instrumen dapat dilihat dari besaran koefisien reliabilitas, instrumen yang reliabel adalah instrumen yang apabila digunakan beberapa kali untuk mengukur objek yang sama akan menghasilkan data yang sama (Sugiyono, 2008). Uji validitas dilakukan di kelas VIII A SMP Negeri 1 Sukasada.

Untuk menganalisis data yang diperoleh digunakan teknik analisis inferensial parametrik. Analisis inferensial parametrik digunakan untuk menguji suatu hipotesis penelitian yang diajukan peneliti. Pengujian hipotesis yang digunakan dalam penelitian ini adalah uji manova. Uji manova digunakan untuk menyelidiki perbedaan satu variabel independen terhadap dua variabel dependen dan untuk menyelidiki perbedaan satu variabel independen terhadap satu variabel dependen. Sebelum dilakukan pengujian hipotesis untuk mendapatkan simpulan, maka prasyarat yang harus dipenuhi adalah melakukan uji normalitas sebaran data, homogenitas varian, dan homogenitas matrik. Data dikatakan berdistribusi normal apabila signifikansi yang diperoleh $>5 \%$. Uji normalitas dapat digunakan dengan mengguanakan bantuan SPSS 17.0 for windows. Uji homogenitas varian digunakan untuk memperoleh data empiris bahwa perbedaan pada uji hipotesis benar-benar terjadi akibat adanya perbedaan antara kelompok. Data dikatakan homogen apabila signifikansi yang diperoleh $>5 \%$. Uji homogenitas varian dapat dilakukan dengan menggunakan bantuan SPSS 17.0 for windows. Candiasa (2011) menyatakan, uji homogenitas matrik varian/covarian dilihat dari uji Box. Kriteria pengujian, jika angka signifikansi yang diperoleh > 5\% maka hipotesis nol diterima. Artinya kelompok-kelompok data yang dibandingkan memiliki varian yang homogen. Uji homogenitas matrik varian/covarian dapat dilakukaan dengan bantuan SPSS 17.0. for windows.

\section{HASIL DAN PEMBAHASAN Hasil Penelitian}

Hasil analisis yang menunjukkan Perbedaan aktivitas belajar antara kelompok siswa yang dibelajarkan model pembelajaran kooperatif tipe make a match dan kelompok siswa yang dibelajarkan dengan model konvensional pada mata pelajaran IPS siswa kelas VIII SMP Negeri 1 Sukasada. Hasil output SPSS 17.0 for windows dapat dilihat pada Tabel 1.

Berdasarkan tabel 1 di bawah nampak bahwa nilai $F_{\text {hitung }} 4,411$ dan memiliki nilai signifikansi sebesar 0,040 $<0,05$. Dengan demikian, hipotesis $\mathrm{H}_{0}$ ditolak dan hipotesis alternatif $\left(\mathrm{H}_{\mathrm{a}}\right)$ diterima. Hal ini berarti terdapat perbedaan aktivitas belajar antara kelompok siswa yang dibelajarkan menggunakan model pembelajaran kooperatif tipe make a match dan kelompok siswa yang dibelajarkan dengan menggunakan model konvensional .

Hasil analisis yang menunjukkan terdapat perbedaan hasil belajar antara kelompok yang dibelajarkan model pembelajaran kooperatif tipe make a 
match dan kelompok siswa yang dibelajarkan dengan model pembelajaran konvensional mata pelajaran IPS siswa kelas VIII SMP Negeri 1 Sukasada. Hasil output SPSS 17.0 for windows nampak pada tabel

Tabel 1. Hasil Uji Manova variabel Independen terhadap 1 Variabel Dependen Uji Test of Between-Subjects Effects

\begin{tabular}{llrrrrrr}
\hline \multirow{2}{*}{ Source } & Dependent & Variable & $\begin{array}{c}\text { Type III Sum } \\
\text { of Squares }\end{array}$ & Df & Mean Square & \multicolumn{1}{c}{ F } & \multicolumn{1}{c}{ Sig. } \\
\hline Corrected & Aktivitas_Belajar & $32.585^{\mathrm{a}}$ & 1 & 32.585 & 4.411 & .040 \\
Model & Hasil_Belajar & $4075.717^{\mathrm{b}}$ & 1 & 4075.717 & 254.353 & .000 \\
Intercept & Aktivitas_Belajar & 11814.403 & 1 & 11814.403 & 1599.298 & .000 \\
& Hasil_Belajar & 329907.717 & 1 & 329907.717 & 20588.530 & .000 \\
Y & Aktivitas_Belajar & 32.585 & 1 & 32.585 & 4.411 & .040 \\
& Hasil_Belajar & 4075.717 & 1 & 4075.717 & 254.353 & .000 \\
Error & Aktivitas_Belajar & 391.524 & 53 & 7.387 & & \\
& Hasil_Belajar & 849.265 & 53 & 16.024 & & \\
Total & Aktivitas_Belajar & 12265.000 & 55 & & & \\
& Hasil_Belajar & 336277.000 & 55 & & & \\
Corrected & Aktivitas_Belajar & 424.109 & 54 & & & \\
Total & Hasil_Belajar & 4924.982 & 54 & & & \\
\hline
\end{tabular}

Berdasarkan tabel 1 di atas tampak bahwa nilai $F_{\text {hitung }}$ adalah 254,353 dan nilai signifikansi sebesar $0,000<0,05$. Dengan demikian, hipotesis $\mathrm{H}_{0}$ ditolak dan hipotesis alternatif $\left(\mathrm{H}_{\mathrm{a}}\right)$ diterima.Hal ini berarti terdapat perbedaan hasil belajar

antara kelompok siswa yang dibelajarkan dengan model pembelajaran kooperatif tipe make a match dan kelompok siswa yang dibelajarkan dengan model pembelajaran konvensional siswa kelas VIII.

Tabel 2. Hasil Uji Manova Variabel Independen Terhadap 2 Variabel Dependen Multivariate Tests ${ }^{b}$

\begin{tabular}{llrrrrc}
\hline Effect & & \multicolumn{1}{c}{ Value } & \multicolumn{1}{c}{$\mathrm{F}$} & Hypothesis df & Error df & Sig. \\
\hline Intercept & & 1.000 & $80194.460^{\mathrm{a}}$ & 2.000 & 52.000 & .000 \\
& Willai's Trace & .000 & $80194.460^{\mathrm{a}}$ & 2.000 & 52.000 & .000 \\
& Wilks' Lambda & 3084.402 & $80194.460^{\mathrm{a}}$ & 2.000 & 52.000 & .000 \\
& Hotelling's Trace & 3084.402 & $80194.460^{\mathrm{a}}$ & 2.000 & 52.000 & .000 \\
$\mathrm{Y}$ & .982 & $1401.209^{\mathrm{a}}$ & 2.000 & 52.000 & .000 \\
& Roy's Largest Root & .018 & $1401.209^{\mathrm{a}}$ & 2.000 & 52.000 & .000 \\
& Pillai's Trace & 53.893 & $1401.209^{\mathrm{a}}$ & 2.000 & 52.000 & .000 \\
& Wilks' Lambda & 53.893 & $1401.209^{\mathrm{a}}$ & 2.000 & 52.000 & .000 \\
& Hotelling's Trace & & & &
\end{tabular}

Hasil analisis yang menunjukkan terdapat perbedaan aktivitas dan hasil belajar antara kelompok siswa yang belajar dengan menggunakan model pembelajaran kooperatif tipe make a match kelompok siswa yang belajar dengan model konvensional pada siswa kelas VIII. Hasil output SPSS 17.0 for windows dapat dilihat pada tabel 2.
Hasil pengolahan data menunjukkan bahwa nilai $F$ untuk pillai's Trace Wilk's Lambda, Hotelling's Trace, Roy's Largest Root memiliki $F_{\text {hitung }} 1401,209$ dan memiliki signifikansi sebesar $0,000<0,05$. Hal ini berarti $\mathrm{F}$ untuk pillai's Trace Wilk's Lambda, Hotelling's Trace, Roy's Largest Root semuanya signifikan. Jadi terdapat perbedaan aktivitas dan hasil belajar 
antara kelompok siswa yang belajar dengan menggunakan model pembelajaran kooperatif tipe make a match dan kelompok siswa yang belajar dengan model pembelajaran konvensional pada siswa kelas VIII.

\section{Pembahasan}

Perbedaan aktivitas belajar antara kelompok yang dibelajarkan model pembelajaran kooperatif tipe make a match dan kelompok siswa yang dibelajarkan dengan model konvensional mata pada pelajaran IPS siswa kelas VIII SMP N 1 Sukasada.

Hasil penelitian yang telah dilakukan menunjukkan bahwa terdapat perbedaan aktivitas belajar siswa yang dibelajarkan dengan model pembelajaran kooperatif tipe make a match dengan siswa yang dibelajarkan dengan model konvensional. Hal ini dapat dilihat pada hasil signifikan sebesar $0.040<0.05$. sehingga dapat disimpulkan bahwa hipotesis nol $\left(\mathrm{H}_{0}\right)$ ditolak dan hipotesis alternatif $\left(\mathrm{H}_{\mathrm{a}}\right)$ diterima, perhitungan uji manova menggunakan bantuan SPPS 17.0 for windows.

Berdasarkan dari hasil pengamatan penulis selama penelitian, terlihat peserta didik pada kelas eksperimen lebih aktif dalam mengikuti proses pembelajaran di dalam kelas dibandingkan dengan kelas kontrol. Hal ini disebabkan adanya rasa tanggung jawab peserta didik untuk dapat menyelesaikan tugas yang telah diberikan pendidik atau guru dalam hal ini mencari kartu pasang. Hal ini menimbulkan semangat dan atusias siswa dalam mengikuti pembelajaran. Hal ini sejalan dengan teori Huda (2014) pembelajaran kooperatif tipe make a match dapat meningkatkan aktivitas belajar siswa baik secara kognitif maupun fisik, meningkatkan pemahaman siswa terhadap materi yang dipelajari, dapat meningkatkan motivasi belajar siswa, meningkatkan gairah belajar siswa, dan efektif sebagai sarana melatih keberanian siswa untuk tampil presentasi.

Perbedaan hasil belajar antara kelompok yang dibelajarkan dengan model pembelajaran kooperatif tipe make a match dan kelompok siswa yang dibelajarkan dengan model konvensional pada mata pelajaran IPS kelas VIII SMP N 1 Sukasada.

Hasil penelitian yang telah dilakukan menunjukkan bahwa terdapat perbedaan hasil belajar siswa yang dibelajarkan dengan model pembelajaran kooperatif tipe make a match dengan siswa yang dibelajarkan dengan model konvensional. Hal ini dapat dilihat pada hasil signifikan sebesar $0.000<0.05$. sehingga dapat disimpulkan bahwa hipotesis nol $\left(\mathrm{H}_{0}\right)$ ditolak dan hipotesis alternatif $\left(\mathrm{H}_{\mathrm{a}}\right)$ diterima, perhitungan uji manova menggunakan bantuan SPPS 17.0 for windows.

Berdasarkan dari hasil pengamatan penulis selama penelitian, terlihat siswa pada kelas eksperimen lebih bersemangat dalam mengikuti pembelajaran dibandingkan dengan kelas kontrol. Hal ini dikarenakan siswa lebih aktif dalam proses pembelajaran dan siswa belajar berusaha untuk mencocokkan kartu pasang tanpa disadari siswa mampu mengingat materi yang dibahas pada saat proses pembelajaran berlangsung. Kemudian timbulnya rasa tanggung jawab siswa sehingga termotivasi untuk dapat bekerja dan belajar lebih giat lagi agar dapat meningkatkan kemampuannya. Akibatnya siswa lebih bersemangat dalam proses pembelajaran. Mencocokkan kartu pasang dapat dijadikan sebagai sarana yang menyenangkan untuk dapat melihat bagaimana usaha tiap siswa untuk mengingat dan memahami materi pelajaran. Mendorong siswa untuk berpatisipasi dalam pembelajaran dan peserta didik lebih bersemangat dalam belajar, pada kelas kontrol proses pembelajaran menggunakan model pembelajaran konvensional, dimana masih banyak peserta didik yang memperoleh hasil belajar yang rendah disebabkan karena siswa masih fokus pada penjelasan yang disampaikan oleh guru, tidak serius mengikuti pembelajaran, dan kurang inisiatif untuk ikut terlibat langsung dalam proses pembelajaran.

Berdasarkan uraian di atas maka dapat disimpulkan bahwa pembelajaran dengan menggunakan model kooperatif tipe make a match dapat memberikan 
pengaruh yang berarti terhadap hasil belajar siswa. Dengan demikian pembelajaran dengan menggunakan model pembelajaran kooperatif tipe make a match telah dibuktikan secara statistik dapat menjawab permasalahan dalam penelitian ini, sehingga hipotesis nol $\left(\mathrm{H}_{0}\right)$ ditolak dan hipotesis alternatif $\left(\mathrm{H}_{\mathrm{a}}\right)$ diterima, perhitungan uji manova menggunakan bantuan SPPS 17.0 for windows.

Hasil penelitian ini sejalan dengan Yulia (2015) menemukan bahwa, hasil belajar model pembelajaran kooperatif tipe make a match lebih baik dari pada siswa yang mengikuti pembelajaran dengan model konvensional. Begitu pula penelitian yang dilakukan oleh Wiguna (2014) menyatakan bahwa terdapat perbedaan hasil belajar yang signifikan antara siswa yang mengikuti pembelajaran dengan model make a match dan siswa yang mengikuti pembelajaran dengan model ceramah.

Perbedaan aktivitas dan hasil belajar antara kelompok yang dibelajarkan dengan model kooperatif tipe make a match dan kelompok yang dibelajarkan dengan model konvensional pada mata pelajaran IPS siswa kelas VIII SMP Negeri 1 Sukasada.

Hasil penelitian yang telah dilakukan menunjukkan bahwa terdapat perbedaan yang signifikan pada tingakat aktivitas belajar dan hasil belajar siswa antara kelompok siswa yang dibelajarkan model pembelajaran kooperatif tipe make a match dan kelompok siswa yang dibelajarkan dengan model konvensional. Hal ini dapat dilihat pada tabel multivariate Test di atas, didapatkan nilai signifikan Pillai's Treace, Wilks'Lambda, Hotelling's Trice, dan Roy's Larget Root sebesar $0.000<0,05$. Sehingga dapat disimpulkan bahwa hipotesis nol $\left(\mathrm{H}_{0}\right)$ ditolak dan hipotesis alternatif $\left(\mathrm{H}_{\mathrm{a}}\right)$ diterima. Jadi terdapat perbedaan aktivitas dan hasil belajar IPS antara kelompok siswa yang dibelajarkan dengan model pembelajaran kooperatif tipe make a match dan kelompok siswa yang dibelajarkan dengan model konvensional.

Berdasarkan dari hasil pengamatan penulis selama penelitian, terlihat siswa pada kelas eksperimen lebih aktif dalam mengikuti proses pembelajaran di dalam kelas dibandingkan dengan kelas kontrol. Selama proses pembelajaran berlangsung, semua siswa terlihat aktif dan antusias dalam mencocokkan kartu soal dan kartu jawaban yang diberikan oleh guru. Siswa nampak bersemangat dalam mencocokkan kartu soal dan kartu jawaban yang dipegang oleh masingmasing siswa. Tidak ada siswa yang pasif, semua siswa antusias mencocokkan kartu soal dan kartu jawaban agar mendapatkan hasil yang tepat. Setiap peserta didik mempunyai kemampuan yang berbedabeda sehingga dalam kegiatan pembelajaran tersebut, terlihat bahwa siswa yang kurang mampu di dalam kelompoknya akan dibantu oleh anggota kelompok yang lain, sehingga semua siswa dapat menjawab soal-soal yang diberikan oleh guru. Dengan adanya kartu soal dan kartu jawaban yang dipegang siswa secara acak, membuat siswa sangat antusias dan bersemangat untuk menemukan jawaban yang tepat dari kartu yang dipegang oleh masing-masing siswa. Hal ini membuat pembelajaran semakin menyenangkan, karena masing-masing siswa berlomba-lomba untuk mencocokkan kartu yang dipegang sebelum waktu yang ditentukan bersama itu berakhir.

Dengan demikian, siswa merasa pembelajaran IPS sangat menyenangkan, dan siswa tidak cepat merasa bosan dalam belajar. Setelah siswa selesai mencocokkan kartu soal dan kartu jawaban, siswa diberikan kesempatan oleh guru untuk mempresentasikan hasil kerjanya, kemudian diberi tanggapan oleh kelompok lain. Hal ini membuat siswa merasa dihargai sehingga siswa akan lebih termotivasi dalam menyelesaikan soal-soal berikutnya dan siswa lebih aktif dalam menanggapi pertanyaan dari guru maupun pendapat dalam berdiskusi. Hal ini sejalan dengan teori Trianto (2009) dalam pembelajaran dikehendakinya susunan kelas berbentuk pembelajaran kooperatif antar siswa, sehingga siswa dapat berinteraksi di sekitar tugas-tugas yang sulit dan saling membantu dalam memecahkan masalah. Pada kelas 
eksperimen siswa yang harus lebih aktif dan guru hanya sebagai fasilitator sehingga suasana kelas lebih menyenangkan. Pada kelas kontrol cendrung pasif karena dalam proses pembelajaran berpusat kepada guru sehingga pembelajaran menjadi membosankan dan mononton, dan kurang keikutsertaan siswa dalam proses pembelajaran.

Berdasarkan uraian di atas maka dapat disimpulkan bahwa pembelajaran dengan menggunakan model kooperatif tipe make a match dapat memberikan pengaruh yang berarti terhadap aktivitas dan hasil belajar siswa. Dengan demikian pembelajaran dengan menggunakan model pembelajaran kooperatif tipe make a match telah dibuktikan secara statistik dapat menjawab permasalahan dalam penelitian ini, sehingga dapat disimpulkan bahwa hipotesis nol $\left(\mathrm{H}_{0}\right)$ ditolak dan hipotesis alternatif $\left(\mathrm{H}_{\mathrm{a}}\right)$ diterima, perhitungan uji manova menggunakan bantuan SPPS 17.0 for windows. Sejalan dengan penelitian Rahayu \& Santoso (2018), menyatakan bahwa, penerapan model pembelajaran kooperatif tipe make a match dapat meningkatkan aktivitas dan hasil belajar siswa.

\section{SIMPULAN DAN SARAN Simpulan}

Berdasarkan hasil penelitian dan pembahasan maka dapat disimpulkan sebagai berikut. Terdapat perbedaan aktivitas belajar antara kelompok siswa yang dibelajarkan model pembelajaraan kooperatif tipe make a match dengan model konvensional pada mata pelajaran IPS siswa kelas VIII di SMP Negeri 1 Sukasada. Hal ini ditunjukkan dengan nilai $F_{\text {hitung }} 4,411$ dan memiliki nilai signifikansi sebesar $0,040<0,05$.

Terdapat perbedaan hasil belajar antara kelompok yang dibelajarkan dengan model pembelajaraan kooperatif tipe make a match dengan model konvensional pada mata pelajaran IPS siswa kelas VIII di SMP Negeri 1 Sukasada. Hal ini ditunjukkan dengan nilai $F_{\text {hitung }}$ adalah 254,353 dan nilai signifikansi sebesar $0,000<0,05$.
Terdapat perbedaan aktivitas dan hasil belajar antara kelompok yang dibelajarkan model pembelajaraan kooperatif tipe make a match dengan model konvensional pada mata pelajaran IPS siswa kelas VIII di SMP Negeri 1 Sukasada. Hal ini ditunjukkan dengan nilai F untuk pillai's Trace Wilk's Lambda, Hotelling's Trace, Roy's Largest Root memiliki $F_{\text {hitung }} 1401,209$ dan memiliki signifikansi sebesar 0,000 0,05.

\section{Saran}

Saran yang disampaikan berdasarkan penelitian yang dilakukan di kelas VIII SMP Negeri 1 Sukasada, adalah sebagai berikut.

Saran pertama untuk guru, yaitu dari hasil penelitian yang telah peneliti lakukan dengan menggunakan model pembelajaran kooperatif tipe make a match terdapat dampak positif yang didapatkan selama proses pembelajaran berlangsung, alangkah baiknya jika hasil penelitian ini bisa diterapkan oleh guru dalam proses pembelajaran di kelas untuk memperkaya model pembelajaran yang dapat membuat siswa tidak mudah jenuh dalam proses pembelajaran, pembelajaran menjadi lebih menyenangkan, dan siswa menjadi lebih aktif dalam belajar. Selain itu, peneliti mengharapkan untuk bisa menerapkan model pembelajaran lainnya yang menarik dan bervariasi sesuai dengan materi pelajaran dan karakteristik siswa dalam rangka meningkatkan aktivitas dan hasil belajar siswa.

Saran kedua untuk siswa, yaitu Sebaiknya siswa aktif dalam kegiatan pembelajaran, aktif memberikan tanggapan, terlibat langsung, dan siswa lebih proaktif mencari sumber belajar lain sebagai tambahan referensi dalam pembelajaran tanpa menunggu perintah dari guru, karena pelajaran IPS adalah pelajaran yang sangat penting untuk semua bidang pekerjaan dan kehidupan sehingga perlu dipelajari.

\section{DAFTAR PUSTAKA}

Arikunto, Suharsimi. 2013. Prosedur Penelitian Suatu Pendekatan Praktik. Jakarta: Rineka Cipta. 
Candiasa. 2011. Pengujian Instrumen Penelitian Disertai Aplikasi ITEMAN Dan BIGSTEPS. Singaraja: Undiksha.

Hamalik, Oemar. 2008. Kurikulum Dan Pembelajaran. Jakarta: Sinar Grafika.

Huda, Miftahul. 2014. Model-Model Pengajaran Dan Pembelajaran. yogyakarta: Pustaka Belajar.

Komalasari, Kokom. 2013. Pembelajaran Kontekstual Konsep Dan Aplikasi. Bandung: Refika Aditama.

Rahayu \& Santoso. 2018. Penerapan Model Pembelajaran Kooperatif Tipe Make A MatchUntuk Meningkatkan Aktivitas Dan Hasil Belajar Siswa Kelas III Pada Tema Harga Diri Di SDN Plalangan 02. Jurnal PGSD FKIP Universitas Jember Vol 6 No 1.

Rusman. 2012. Model-Model Pembelajaran. Jakarta: PT Raja Grafindo Persada.

Sagala, Syaiful. 2010. Konsep Dan Makna Pembelajaran. Bandung: Alfabeta.

Sardiman. 2011. Interaksi Dan Motivasi Belajar Mengajar. Jakarta: PT Raja Grafindo Persada.

Slameto. 2015. Belajar Dan Faktor-Faktor Yang Mempengaruhinya. Jakarta: Rineka Cipta.

Sugiyono. 2008. Metode Penelitian Kuantitatif Kualitatif Dan $R \& D$. Bandung: Alfabeta.

Trianto. 2009. Mendisain Model Pembelajaran Inovatif-Proresif. Surabaya: Kencana.

Wiguna, Adi. 2014. Pengaruh Model Pembelajaran Kooperatif Tipe Make A Match Terhadap Hasil Belajar Matematika Siswa Kelas IV Di Gugus III Kecamatan Rendang. Jurnal Mimba PGSD Universitas Pendidikan Ganesha.

Yulia, Afriani. 2015. Pengaruh Model Kooperatif Tipe Make A Match Terhadap Hasil Belajar Matematika Siswa Kelas VII SMP Negeri 9 Lubuklinggau. STKIP-PGRI 